\title{
EFFECTS OF TETRA HYDRO CANNABINOL TO THE DENDRITC TREE AND SYNAPSES OF THE ACCUMBENS NUCLEUS OF WISTAR RATS
}

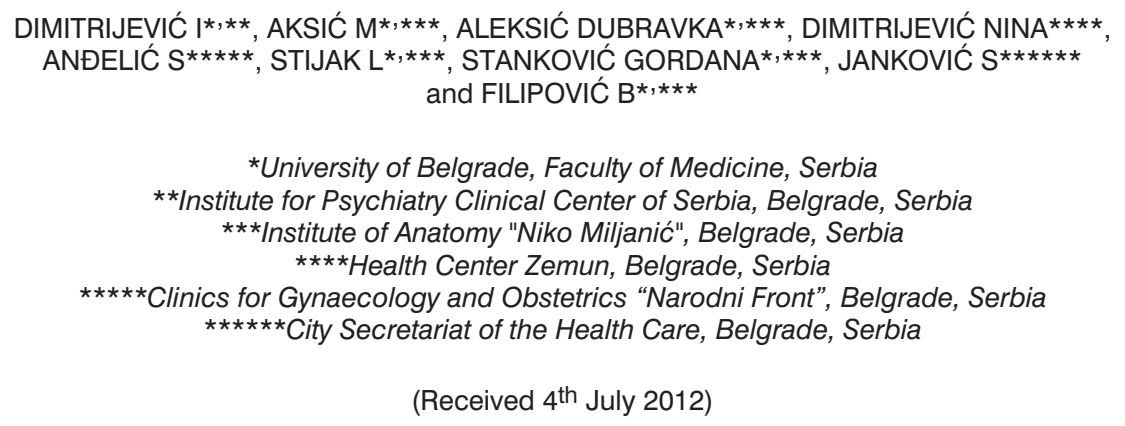

Cannabis is one of the most widely used intoxicants; almost half of all 18 year olds in the USA and in most European countries admit to having tried it at least once, and $\sim 10 \%$ of that age group are regular users. $\Delta^{9}$-Tetrahydrocannabinol (THC), the principal psychoactive ingredient in marijuana, produces euphoria and relaxation and impairs motor coordination, time sense, and short term memory. In the hippocampus, CBs inhibit GABA release from a subset of interneurons and inhibit glutamate release from principal neurons. Cannabinoids are reported to produce both rapid and long-term changes in synaptic transmission. Our study was carried out on ten male rats out of which brains of six of them were used as the representative sample for electron microscope analysis, while 4 were used for light microspcopy performed by Golgi method. Three were exposed to THC and 3 were controls. Axodendric synapses in the core and shell of the accumbens nucleus (AN) were studied under electron microscope. The results have shown widening of the synaptic cleft in the shell of AN. This result is a leading point to our further investigations which are going to involve a behavioral component, and different aspects of morphological studies.

Key words: axodendric synapse, Cannabis sativa, septal region, shell of accumbens nucleus

\section{INTRODUCTION}

Despite being illegal, cannabis is one of the most widely used intoxicants; almost half of all 18 year olds in the USA and in most European countries admit to having tried it at least once, and $\sim 10 \%$ of that age group are regular users (Iversen, 2000). 
Acta Veterinaria (Beograd), Vol. 63, No. 1, 37-44, 2013. al.: Effects of Tetra hydro cannabinol to the dendritc tree and synapses of the accumbens nucleus of Wistar rats

$\Delta^{9}$-Tetrahydrocannabinol (THC), the principal psychoactive ingredient in marijuana, produces euphoria and relaxation and impairs motor coordination, time sense, and shor tterm memory (Ameri, 1999). Clinically useful attributes of the cannabinoids (CBs) include their ability to produce analgesia, reduce chemotherapy-induced emesis, stimulate appetite, and attenuate seizures and spasticity (Croxford, 2003). In the hippocampus, CBs inhibit GABA release from a subset of interneurons and inhibit glutamate release from principal neurons. Cannabinoids are reported to produce both rapid and long-term changes in synaptic transmission. (Katona et al., 1999; Domenici et al., 2006). Some previous investigations are pointing toward the enlargement of the synaptic cleft in the septal region under the influence of THC (Harper et al., 1977), although prolonged exposure to WIN55,212-2, (THC agonist) but not THC, desensitized the protective effect. Treating cells that had undergone postsynaptic density protein loss with WIN55,212-2 reversed the loss and enabled recovery of a full complement of synapses (Kim et al., 2008).

The nucleus accumbens, divided in two parts, core and shell, has already been reported as the target of changes in THC dependence withdrawal, according to the deterioration of the dopaminergic system (Spiga et al., 2011).

The aim of our study was to evaluate the influence of THC on the synapses of both parts, core and shell of the accumbens nucleus in rats, prior to continuing our study with THC effects on the brains of different species, including humans.

\section{MATERIALS AND METHODS}

\section{Subjects}

Ten male Wistar rats weighing 280-300 g, were housed in groups of four in a temperature $\left(21 \pm 1^{\circ} \mathrm{C}\right)$ and humidity $(55 \pm 5 \%)$ controlled environment in wire cages (solid bottom cages, $59.0 \times 38.5 \times 20.0 \mathrm{~cm}$ ). The animals had free access to food pellets and water and were kept on a 12-h light/dark cycle (lights on 7:00 PM7:00 AM). The animals were handled daily for at least 1 week prior to surgery. Rats were administered twice a day (08:00 a.m. and 20:00 p.m.), for 6.5 days with $\Delta^{9}$ THC (Sigma, Milano, Italy) emulsified in $1 \%$ Tween 80 , then diluted in saline solution and administered intraperitoneally, in a volume of $3 \mathrm{~mL} / \mathrm{kg}$.

The coordinates (Paxinos) with respect to the bregma were as follows: Nucleus accumbens shell lesions: (1) $+1.7 \mathrm{~mm}$ anterior (AP) to bregma; $\pm 1.1 \mathrm{~mm}$ lateral $(\mathrm{L})$ to the midline; and dorsoventral (DV) $-6.4 \mathrm{~mm}$ below the dura; (2) AP, +1.7 mm; L, $\pm 1.1 \mathrm{~mm}$; DV, -6.9; (3) AP, +1.7 mm; L, $\pm 1.1 \mathrm{~mm}$; and DV, -7.9 mm.

\section{Perfusion procedure and tissue preparation}

After a recovery period of 4 weeks, rats were subjected to an extensive behavioral analysis. Care was taken not to use one animal in more than three behavioral procedures. After completion of the behavioral experiments, rats were deeply anaesthetized with Nembutal $(60 \mathrm{mg} / \mathrm{kg}$, ip) and, after loss of the corneal reflex, were perfused with a solution of $0.9 \% \mathrm{NaCl}$ solution at room temperature for $2 \mathrm{~min}$ at a flow rate of $30 \mathrm{~mL} / \mathrm{min}$ followed by $4 \%$ paraformaldehyde (Sigma) in $0.1 \mathrm{M}$ phosphate buffer (Sigma) at $4^{\circ} \mathrm{C}(\mathrm{pH} 7.2)$ at a flow rate of $30 \mathrm{~mL} / \mathrm{min}$ for 15 
min. The descending aorta was clamped, and the animal's head was packed with ice during the entire perfusion.

Brains of the four animals (two exposed and two controls) were taken for light micropscopy peroformed by Golgi staining. Blocks of brains cut accordingly to the coordinates of Paxinos atlas were cut from $1 \mathrm{~cm}$ thick coronal sections through fresh brain in the region anterior to the decussating anterior commissure and were immediately immersion fixed in 2.5\% glutaraldehyde, 2\% paraformaldehyde in $0.1 \mathrm{M}$ phosphate buffer $(\mathrm{pH} 7.4)$. The Golgi-impregnation technique was applied to these blocks [1\% osmium tetroxide $(4 \mathrm{~h}), 3.5 \%$ potassium dichromate (3 days) and $0.75 \%$ silver nitrate (approximately $16 \mathrm{~h}$ )] or to $100 \mu \mathrm{m}$ vibratome sections cut from the $5 \mathrm{~mm}^{3}$ blocks [ $1 \%$ osmium tetroxide (40 $\mathrm{min}), 3.5 \%$ potassium dichromate $(18 \mathrm{~h})$ and $1 \%$ silver nitrate sandwiched between two slides (approximately $6 \mathrm{~h}$ ); Bolam and Ingham, 1990]. Golgiimpregnated blocks were subsequently sectioned on a vibrating microtome at $100 \mu \mathrm{m}$. All sections were dehydrated in graded ethyl alcohol (50\%, $5 \mathrm{~min} ; 70 \%$, $30 \mathrm{~min}$; 95\%, $15 \mathrm{~min}$; 100\%, 15 min x2; propylene oxide, $10 \mathrm{~min} \times 2$ ), embedded in resin (Durcupan, ACM; Fluka), mounted on slides and coverslipped. The resin was polymerized at $60^{\circ} \mathrm{C}$ for $48 \mathrm{~h}$ (Bolam and Ingham, 1990).

The longest dendrite (selected qualitatively) from 30 medium sized spiny neurones from both the shell and core of the accumbens nucleus of each control subject and PD patient was quantitatively analyzed with regard to spine numbers (Figure 1) using a computer-aided tracing system (Neurolucida; Microbrightfield Inc., USA). The spine numbers were expressed as spines per $10 \mu \mathrm{m}$ of dendrite from the soma to the distal tip (Stephens et al., 2005). Total dendritic length was calculated by the method established by Sholl et al. (1953).

For the electron microscope analysis, the animal's head was placed in $4 \%$ paraformaldehyde in $\mathrm{PB}$ overnight at $4^{\circ} \mathrm{C}$. The following day, the brains were extracted from the skull and placed in a solution of $30 \%$ sucrose in $0.1 \mathrm{M} \mathrm{PBS}, \mathrm{pH}$

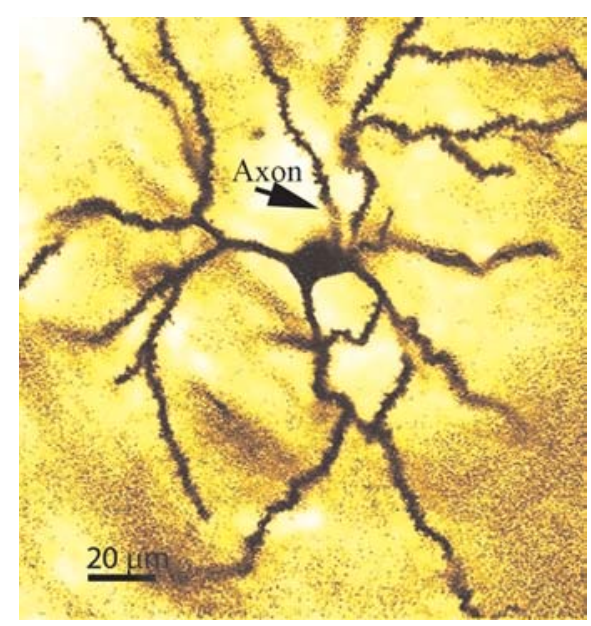

Figure 1. Golgi impregnated medium size neuron from nucleus accumbens 
Acta Veterinaria (Beograd), Vol. 63, No. 1, 37-44, 2013.

al.: Effects of Tetra hydro cannabinol to the dendritc tree and synapses of the accumbens nucleus of Wistar rats

7.4 for $1-2$ days at $4^{\circ} \mathrm{C}$ under gentle agitation. The brains were cut on a freezing microtome into five adjacent series of $40-\mu \mathrm{m}$-thick coronal sections. A one-in-five series was mounted immediately onto gelatin-coated slides and stained with Nissl method. The other series were collected into a cryoprotectant solution (30\% ethylene glycol $25 \%$ glycerol in $50 \mathrm{mM} \mathrm{PB}, \mathrm{pH} 7.4$ ) and were stored at $-20^{\circ} \mathrm{C}$ until used. After the Nissl staining, the sections were dehydrated through an alcohol series, cleared with xylene and coverslipped with DPX (BDH, Poole, England).

Samples of the tissue were placed in a cold fixative for 1 hour and then postfixed in cold $1.5 \%$ osmium tetroxyde dehydrated through cold graded ethanols; and flat-embedded in Epon 812. Sections encompassing the entire depth $(1.8 \mathrm{~mm}$ ) of the sample site were cut on a Leica RM2265 (Leica Inc, GmBH) ultramicrotome at $600 \mathrm{~nm}$ in thickness. Semithin sections were stained with toluidin blue. Thin sections were stained with uranyl acetate and lead citrate (Venable and Coggeshall, 1965) and viewed with a Philips EM-420 electron microscope. Samples for quantitative study were randomly coded so that the investigators were unaware of the rat source of the tissue under study. Photographic plates taken for measurement were standardized for magnification $(39,000 \mathrm{X})$ and enlarged with a 3.75 print factor.

Synapses of the same morphologic type from tissues of the 6 representative brains (3 THC exposed and 3 controls) were compared.

Axodendritic synapses, as already described by Harper et al. (1977) were observed and measured. These synapses are characterized by a thickened postsynaptic cytoplasmic opacity bordering the region of synaptic contact and by a population of spherical vesicles. Only those fine structures with clear pre- and postsynaptic membranes were included, so as to ensure exact cross-sectional measurement of the cleft (Harper et al., 1977). We used 120 representative figures (60 from the experimental and 60 from the control groups). All the photos were, after calibration measured by freeware available from the Internet (Scion Image, Scion Inc. USA).

Statistical analysis comprehended the usual measures of central tendency and test of mean difference by t-test for independent samples at 95\% probability level.

\section{RESULTS}

The shell part of the nucleus accumbens seemed to be more susceptive to the THC influence. The THC application affected total dendritic length and, subsequently, number of spines at $10 \mu \mathrm{m}$ length (Tables 1 and 2).

In non exposed rats, dendrites are evident in various sectional planes and an electron-lucent intercellular space which varied from $8-13 \mathrm{~nm}$ separates all tissue components. Axodendritic synapses are characterized by a presynaptic button, with a complement of spherical synaptic vesicles, a distinct synaptic cleft, and a postsynaptic dendrite. The synaptic cleft region of such a synapse was observed under $80,000 \times$ magnification. The presynaptic membrane, the cleft 
Acta Veterinaria (Beograd), Vol. 63, No. 1, 37-44, 2013.

Dimitrijević I et al.: Effects of Tetra hydro cannabinol to the dendritc tree and synapses of the accumbens nucleus of Wistar rats

region, about $18 \mathrm{~nm}$ in width, and the postsynaptic membrane with its subsynaptic opacity were clearly visible.

Table 1. Total dendritic length (in $\mathrm{mm}$ ) in rats treaed with $\mathrm{THC}$ and controls

\begin{tabular}{|l|c|c|}
\hline & NA - core & NA - shell \\
\hline \hline Studied & $3232.34 \pm 123.45$ & $3198.56 \pm 223.13$ \\
\hline Controls & $3224.21 \pm 201.71$ & $2241.52 \pm 179.06$ \\
\hline Statistics & NS & $T=14.214, \mathrm{df}=148, \mathrm{p}=0.0000$ \\
\hline
\end{tabular}

NS - non significant

Table 2. Average number of spines / $10 \mathrm{~mm}$ in examined and control groups

\begin{tabular}{|l|c|c|}
\hline & NA - core & NA - shell \\
\hline \hline Studied & 8.2 & 2.8 \\
\hline Controls & 7.6 & 8.4 \\
\hline Statistics & NS & $\chi^{2}=8.02, \mathrm{df}=74, \mathrm{p}=0.000$ \\
\hline
\end{tabular}

In exposed rats, under the same conditions $(80,000 \times$ magnification) a significantly larger synaptic cleft has been obtained in the shell segment of $A N$, but not in the core part (Table 3).

Table 3. Dimension of the synaptic clefts in exposed and unexposed rats (in nm)

\begin{tabular}{|l|c|c|}
\hline Group & Core AN (mean \pm SD) & Shell AN (mean \pm SD) \\
\hline \hline Exposed & $20.31 \pm 1.22$ & $24.45 \pm 3.36$ \\
\hline Unexopsed & $19.87 \pm 0.87$ & $20.34 \pm 2.77$ \\
\hline Statiscs & NS & $P=0.0004, \mathrm{t}=9.68, \mathrm{df}=118$. \\
\hline
\end{tabular}

\section{DISCUSSION}

In this study, authors intended to demonstrate the potential influence of $\Delta^{9}$ tetrahydrocannabinol on the dendritic morpholgy, such as total dendritic length and number of spines, as weel as on the synapses of the accumbens nucleus in rats. We have established that there is a difference in the responsiveness of the parts of AN to THC: neurons of the shell part exhibited synaptic enlargement and neurons of the core part measured axodendric synapses width same as unexposed animals.

Two parts of the accumbens nucleus are reported to be sexually dimorphic: core/shell gender differences have been outlined as more expressed in the core region (Forlano and Wooley, 2010). 
Acta Veterinaria (Beograd), Vol. 63, No. 1, 37-44, 2013. al.: Effects of Tetra hydro cannabinol to the dendritc tree and synapses of the accumbens nucleus of Wistar rats

Some recent studies have shown the persistent disparity in core/shell excitability might be an important mediator of the changes in reward circuit activity that drive drug-seeking behavior in animal models of addiction (Kourrich and Thomas 2009). Shell neurons are pointed as less responsive to experimentally induced ethanol seeking in rats (Chaudhri et al., 2010), although the neurotoxicity of THC is reported to be at least ambiguous. However, other investigations lead to the point that the shell part is more responsive for pleasure feeling (de Luca et al., 2011).

Treatment of rats with high doses of THC given orally for 3 months (Scallet et al., 1987) or subcutaneously for 8 months (Landfield et al., 1988) was reported to lead to neural damage in the hippocampal CA3 zone, with shrunken neurons, reduced synaptic density and loss of cells (Chan et al., 1998). However, in another study the potent synthetic cannabinoid WIN55,2122 was administered twice daily ( $2 \mathrm{mg} / \mathrm{kg}$ ) to rats and led to an apparent increase in hippocampal granule cell density, and increased dendritic length in the CA3 zone. In perhaps the most severe test of all, rats and mice were treated with THC 5 days each week for 2 years and no histopathological changes were observed in the brain, even after $50 \mathrm{mg} / \mathrm{kg} /$ day (rats) or $250 \mathrm{mg} / \mathrm{kg} /$ day (mice) (Chan et al., 1996; Iversen, 2003). The widening of the synapse under the influence of THC may lead to both, excitation and attenuation of hippocampal synaptic activity by cannabinoids prevented synapse loss. Excitatory neurons maintain a precarious balance between full integration into excitatory networks, with the associated risk of overstimulation and withdrawal from the network to increase survival, with the associated loss of network function. Modulation of presynaptic CB1 receptors either directly or through modulation of the excitatory CB system may prove to be a useful pharmacologic approach for maintaining this balance during neurodegenerative disease (Kim et al., 2008).

In summary, effects of THC is different from one part of the accumbens nucleus to the second one: in part which is, according to the literature, more related to the reward feeling, the shell of $A N$ widens the synapses while on the other, the core, this effect is not so expressed. Still, further investigation ought to be done to determine the factors leading to synapse changes and to determine the $\mathrm{CB} 1$ receptor density potential differences between the two mentioned parts.

AKNOWLEDGEMENT:

This investigation was partially financed by Grant III 41020 Ministry of Education and Science, Rep. of Serbia

Address for correspondence:

Prof. Dr Branislav Filipović

Institute of Anatomy "Niko Miljanić"

Dr Subotića 4/2

11000 Belgrade, Serbia

E-mail: b.filipovic@med.bg.ac.rs

\section{REFERENCES}

1. Ameri A, 1999, The effects of cannabinoids on the brain, Prog Neurobiol, 58, 315-48. 
2. Bolam JP, Ingham CA, 1990, Combined morphological and histochemical techniques for the study of neuronal microcircuits. In: Handbook of chemical neuroanatomy: neuronal microcircuits: combined morphological, immunocytochemical and electrophysiological techniques for the study of synaptic interactions between identified CNS neurons Vol. 8 (Van den Pol A, Wouterlood F eds), 125-98, Amsterdam, Elsevier.

3. Chan GCK, Hinds TR, Impey S, Storm DR, 1998, Hippocampal neurotoxicity of delta 9tetrahydrocannabinol, J Neurosci, 18, 5322-32.

4. Chan PC, Sills RC, Braun AG, Haseman JK, Bucher JR, 1996, Toxicity and carcinogenicity of delta 9tetrahydrocannabinol in Fischer rats and B6C3F1 mice, Fundam Appl Toxicol, 30, 109-17.

5. Chaudhri N, Sahuque LL, Schairer WW, Janak PH, 2010, Separable roles of the nucleus accumbens core and shell in context- and cue-induced alcohol-seeking. Neuropsychopharmacology, 35, 783-91.

6. Croxford JL, 2003, Therapeutic potential of cannabinoids in CNS disease, CNS Drugs, 17, 179-202.

7. De Luca MA, Solinas M, Bimpisidis Z, Goldberg SR, Di Chiara G, 2011, Cannabinoid facilitation of behavioral and biochemical hedonic taste responses, Neuropharmacology, (e pub) doi 10.1016/j.bbr.2011.03.031

8. Domenici MR, Azad SC, Marsicano G et al., 2006, Cannabinoid receptor type 1 located on presynaptic terminals of principal neurons in the forebrain controls glutamatergic synaptic transmission, J Neurosci, 26, 5794-9

9. Forlano PM, Wooley CS, 2010, Quantitative analysis of pre-and postsynaptic sex differences in the nucleus accumbens, J Comp Neurol, 2010, 518, 1330-48.

10. Harper JW, Heath RG, Myers WA, 1977, Effects of the Cannabis sativa on the ultrastructure of the synapse in monkey brain, $J$ Neurosci Res, 3, 87-93.

11. Iversen L, 2003, Cannabis and brain, Brain, 126, 1252-70.

12. Iversen LL, The science of marijuana, (Review), Oxford, Oxford University Press, 2000.

13. Katona I, Sperlagh B, Sik A et al. 1999, Presynaptically located CB1 cannabinoid receptors regulate GABA release from axon terminals of specific hippocampal interneurons, J Neurosci, 19, 454458

14. Kim HJ, Waataja JJ, Thayer SA, 2008, Cannabinoids inhibit network-driven synapse loss between hippocampal neurons in culture, JNEP, 325, 850-8.

15. Kourrich S, Thomas MJ, 2009 Similar neurons, opposite adaptations: Psychostimulant experience differentially alters firing properties in accumbens core versus shell, J Neurosci, 29, 12275-83.

16. Landfield PW, Cadwallader LB, Vinsant S, 1988, Quantitative changes in hippocampal structure following long-term exposure to delta 9-tetrahydrocannabinol: possible mediation by glucocorticoid systems, Brain Res, 443, 47-62.

17. Scallet AC, Uemura E, Andrews A et al., 1987, Morphometric studies of the rat hippocampus following chronic delta-9-tetrahydrocannabinol (THC), Brain Res, 436,193-8.

18. Sholl $D A, 1953$, Dendritic organization in the neurons of the visual and motor cortices of the cat, $J$ Anat, 87, 387-406.

19. Spiga S, Lintas A, Diana M, 2011, Altered mesolimbic dopamine system in THC dependence, Curr Neuropharmacol, 9, 200-4.

20. Stephens B, Mueller J, Shering AF et al., 2005, Evidence of a breakdown of corticostriatal neurons in Parkinson's disease, Neuroscience, 132, 741-54.

21. Venable $J H$, Coggeshall RA, 1965, A simplified lead citrate stain for use in electron microscropy, $J$ Cell Biol, 25, 407-8. 
Acta Veterinaria (Beograd), Vol. 63, No. 1, 37-44, 2013.

Dimitrijević I et al.: Effects of Tetra hydro cannabinol to the dendritc tree and synapses of the accumbens nucleus of Wistar rats

\section{EFEKAT TETRA HIDRO KANABINOLA NA DENDRITSKU MORFOLOGIJU I SINAPSE U NUCLEUS ACCUMBENS WISTAR PACOVA}

DIMITRIJEVIĆ I, AKSIĆ M, ALEKSIĆ DUBRAVKA, DIMITRIJEVIĆ NINA, ANĐELIĆ S, STIJAK L, STANKOVIĆ GORDANA, JANKOVIĆ S i FILIPOVIĆ B

\section{SADRŽAJ}

Cannabis je jedna od najviše korišćenih psihoaktivnih supstancii noviji podaci potvrđuju da većina mladih u SAD i evropskim zemljama, proba ovu drogu bar jednom, a približno $10 \%$ njih postaju stalni korisnici. $\Delta^{9}$-tetrahidrokanabinol (THC) je aktivni princip marihuane koji uzrokuje euforiju i opuštanje, remeti motornu koordinaciju, dovodi do gubitka osećaja za vreme i kratkotrajnog pamćenja. U hipokampusu, kanabinoidi oštećuju interneurone i GABA otpuštanje kao i kratkotrajnu i dugotrajnu sinaptičku transimisiju. Naše istraživanje je vršeno na 10 zdravih mužjaka pacova soja Wistar, od kojih je 7 korišćeno kao reprezentativni uzorak. Četiri mužjaka su korićena za svetlosno mikroskopske studije Golgi metodom. Tri mužjaka su bila izložena dejstvu THC, a 3 su korišćena kao kontrole. Aksondendritske sinapse u jedru i omotaču nucleus accumbens su posmatrani elektronskim mikroskopom, a širina njihove sinaptičke pukotine je merena pomoću posebnog softvera. Dobijeni rezultati ukazuju da postoji proširenje sinaptičke pukotine u omotaču nucleus accumbens-a, ali ne i u jedarnom delu. 